\title{
PENGARUH PEMBERIAN BERBAGAI KONSENTRASI TEMBAGA (Cu) TERHADAP JUMLAH TRAKEA AKAR ECENG GONDOK
}

\author{
(Eichhornia crassipes)
}

\author{
Anita Munawwaroh, S.Si., M. Si. \\ IKIP Budi Utomo Malang \\ E-mail : munawwarohanita86@gmail.com
}

\begin{abstract}
Abstrak
Keberadaan logam tembaga $(\mathrm{Cu})$ dalam badan perairan sangat berpengaruh terhadap kehidupan makhluk hidup, baik yang ada didalamnya maupun di lingkungan sekitarnya. $\mathrm{Cu}$ bersifat toksik bagi tumbuhan termasuk tumbuhan air seperti Eceng Gondok (E. crassipes). Pengaruh $\mathrm{Cu}$ terhadap tumbuhan dapat diamati dari organ tumbuhan yaitu akar. Akar merupakan bagian tumbuhan yang paling banyak menyerap logam karena tahap pertama dalam proses penyerapan unsur hara adalah melalui akar. Metode yang dilakukan dalam penelitian ini adalah dengan menumbuhkan tiga tanaman E. crassipes. dalam medium air dengan 4 konsentrasi, yaitu konsentrasi 0 ppm, 4 ppm, 8 ppm dan $12 \mathrm{ppm}$ kemudian dibuat preparat permanen dengan metode parafin dan selanjutnya dilakukan pengamatan dengan mikroskop elektrik untuk memperoleh data banyaknya trakea akar E. crassipes. Data yang diperoleh pada penelitian ini dianalisis menggunakan analisis varian satu arah, kemudian dilanjutkan dengan uji Duncan untuk mengetahui letak perbedaannya. Dari hasil analisis menunjukkan bahwa pemberian $\mathrm{Cu}$ dengan berbagai konsentrasi yaitu 0 ppm, 4 ppm, 8 ppm, dan 12 ppm menyebabkan perbedaan jumlah trakea akar E. crassipes. secara nyata. Dimana semakin tinggi konsentrasi $\mathrm{Cu}$ maka jumlah trakea semakin sedikit. Pengaruh $\mathrm{Cu}$ terhadap trakea adalah pada proses pertumbuhan sel. $\mathrm{Cu}$ menghambat proses metabolisme sel dan dapat menurunkan pertumbuhan. Penurunan pertumbuhan ini terjadi karena logam $\mathrm{Cu}$ yang masuk ke dalam sel akan berikatan dengan enzim, sehingga fungsi enzim sebagai katalisator untuk reaksi-reaksi kimia di dalam sel akan mengalami gangguan.
\end{abstract}

Kata Kunci : konsentrasi $\mathrm{Cu}$, jumlah trakea, akar E. crassipes

\section{LATAR BELAKANG}

Pencemaran

lingkungan

merupakan satu masalah yang

memerlukan penanganan serius karena dampak yang ditimbulkannya dapat menurunkan tingkat kesehatan manusia. Pencemaran dapat berasal dari industri di Indonesia yang dapat mencemari perairan, udara, dan tanah akibat kegiatan dan limbah yang dihasilkan industri tersebut. Salah satu jenis logam berat di daerah perairan yang dapat menyebabkan pencemaran lingkungan dan membahayakan kesehatan manusia yaitu Cu (Darmono, 1995). Logam Cu termasuk dalam golongan logam berat esensial karena dibutuhkan dalam 
jumlah sedikit oleh tubuh dan bersifat racun bila masuk kedalam tubuh dalam jumlah besar atau melebihi nilai toleransi (Palar, 2008).

Untuk memantau pencemaran di daerah perairan, umumnya digunakan parameter fisika, kimia maupun biologi. Salah satu pendekatan biologi untuk menilai kualitas lingkungan perairan adalah dengan menggunakan tumbuhan tingkat tinggi. Eceng Gondok (Eichhornia crassipes) merupakan tanaman yang dapat menyerap logam berat. Berdasarkan penelitian Amalia (2007) dapat diketahui bahwa $E$. crassipes mampu menyerap logam $\mathrm{Cu}$, dimana penyerapan paling banyak pada akar dibandingkan pada batang dan daun. Hal tersebut ditunjukkan dengan penyerapan $\mathrm{Cu}$ pada akar, batang dan daun E. crassipes dalam waktu 180 jam masing-masing sebesar 2,170 ppm, 1,187 ppm, dan 0,616 ppm.

Pada lingkungan perairan yang tercemar, tumbuhan dapat menyerap logam berat melalui akar. Masuknya logam berat kedalam tubuh tumbuhan dapat mengganggu pertumbuhan dan perkembangan xilem sebagai salah satu komponen dalam sistem transport. Pertumbuhan xilem salah satunya bisa diamati dari jumlah trakea yang terbentuk (Cahyaningsih, 2004). Pada kondisi yang tercemar logam berat, jumlah trakea lebih sedikit dan ukuran diameter trakea lebih kecil. Hal ini diperkuat dengan penelitian yang dilakukan oleh Suprihatin (2003). Hasil penelitianya menunjukkan bahwa $\mathrm{Cd}$ berpengaruh terhadap jumlah trakea Jussiaea repens. Pada konsentrasi 12 ppm diperoleh jumlah trakea lebih sedikit dibandingkan pada konsentrasi 4 ppm, 8 ppm, dan kontrol. Berdasarkan uraian tersebut, maka perlu diteliti pengaruh pemberian berbagai konsentrasi $\mathrm{Cu}$ terhadap jumlah trakea akar E. crassipes.

\section{METODE PENELITIAN}

Penelitian ini menggunakan rancangan acak lengkap (RAL) dengan satu faktor perlakuan, yaitu konsentrasi $\mathrm{Cu}$ yang terdiri dari empat tingkat $(0 \mathrm{ppm}, \quad 4 \mathrm{ppm}, \quad 8 \mathrm{ppm}$, dan 12 ppm). Pada setiap konsentrasi ditanami 3 buah tanaman Eceng gondok ( E. Crassipes) dimana masing-masing tanaman tersebut akan diambil 3 akar. Adapun prosedur penelitian adalah sebagai berikut:

I. Tahap Persiapan dan Pelaksanaan

1. Mengambil tanaman E. crassipes dari habitat awal 
2. Mencuci akar tanaman E. crassipes untuk menghilangkan tanah maupun kotoran yang menempel pada permukaan akar sehingga terlihat bersih.

3. Menyiapkan larutan baku dengan cara menimbang 3,9279 g $\mathrm{CuSO}_{4} 5 \mathrm{H}_{2} \mathrm{O}$ dan dilarutkan dengan aquades sampai volumenya1000 $\mathrm{ml}$ (setara dengan $1000 \mathrm{ppm}$ ) selanjutnya membuat larutan baku dengan konsentrasi 4 ppm, 8 ppm dan $12 \mathrm{ppm}$.

4. Menyiapkan bak plastik. Masing-masing bak di isi dengan 3 liter air sumber yang telah diberi larutan $\mathrm{CuSO}_{4} 5 \mathrm{H}_{2} \mathrm{O}$ dengan berbagai konsentrasi.

5. Menghilangkan akar tanaman $E$. crassipes kemudian meletakkan tanaman tersebut dengan jumlah yang sama yaitu 3 buah tanaman ke dalam masing-masing bak yang telah berisi air sumber dengan berbagai konsentrasi $\mathrm{Cu}$ yang berbeda.

6. Menunggu masa tanam (kontak) sampai akar tanaman $E$. crassipes berukuran $\pm 3 \mathrm{~cm}$ untuk di ambil akarnya.
II. Tahap Pemanenan

1. Mengambil akar tanaman $E$. crassipes setelah berukuran $\pm 3 \mathrm{~cm}$.

2. Memotong akar dan memasukkan akar yang telah diambil ke dalam botol fial yang berisi larutan fiksatif FAA.

III. Tahap Pembuatan Preparat Mengambil akar $E$. crassipes dari botol fial yang berisi larutan FAA kemudian membuat preparat melintang akar secara permanen dengan menggunakan metode parafin dilanjutkan dengan pewarnaan safranin-fast green (Budiono, 1992).

Dari hasil pengamatan trakea akar E. crassipes di analisis dengan menggunakan analisis varian satu arah (ANAVA satu arah). Jika ada perbedaan, dilanjutkan dengan uji DUNCAN.

\section{HASIL DAN PEMBAHASAN}

\section{Hasil Penelitian}

Data rerata hasil pengukuran tekanan osmotik pada penelitian ini disajikan pada Tabel 1: 
Tabel 1. Data Rerata Jumlah Trakea Akar Eceng Gondok

\begin{tabular}{|c|c|c|c|}
\hline \multicolumn{5}{|c|}{ Perlakuan } \\
\hline Konsentrasi 0 ppm & Konsentrasi 4 ppm & Konsentrasi 8 ppm & Konsentrasi 12 ppm \\
\hline 35,33 & 29,33 & 27,33 & 26,67 \\
\hline 36,00 & 29,67 & 28,33 & 25,33 \\
\hline 34,67 & 30,00 & 29,33 & 26,33 \\
\hline 34,33 & 30,33 & 29,67 & 24,33 \\
\hline 36,67 & 30,33 & 27,67 & 25,33 \\
\hline 34,67 & 31,00 & 28,33 & 25,00 \\
\hline 36,00 & 30,33 & 29,33 & 28,00 \\
\hline 37,00 & 31,33 & 26,67 & 30,67 \\
\hline 34,67 & 31,67 & 31,00 & 30,67 \\
\hline
\end{tabular}

Data jumlah trakea akar eceng gondok yang diperoleh dianalisis menggunakan uji statistik. Uji awal yang dilakukan adalah uji kenormalan dan homogenitas data dengan menggunakan uji Kolmogorov-smirnov dan uji Levene Test. Dari uji Kolmogorov-smirnov didapatkan nilai signifikansi sebesar 0,637. Nilai tersebut lebih besar dari $\alpha=0,05$ yang menunjukkan bahwa data jumlah trakea akar eceng gondok berdistribusi normal. Dari uji Levene Test didapatkan nilai signifikansi sebesar 0,123 , nilai tersebut lebih besar dari $\alpha=0,05$ yang menunjukkan bahwa data jumlah trakea akar eceng gondok homogen. Uji Kolmogorov-smirnov dan uji Levene Test menunjukkan bahwa data normal dan homogen sehingga dapat dilanjutkan ke uji ANOVA satu arah untuk mengetahui perbedaan jumlah trakea akar eceng gondok akibat perlakuan berbagai kosentrasi $\mathrm{Cu}$.

Tahap selanjutnya yaitu melakukan uji ANOVA satu arah, Dari uji ANOVA satu arah didapatkan nilai signifikansi sebesar 0,000 . Nilai tersebut lebih kecil dari $\alpha=0,05$ yang artinya $\mathrm{H}_{0}$ ditolak, yakni ada pengaruh berbagai perlakuan salinitas terhadap kapasitas osmoregulasi udang regang. Uji dilanjutkan dengan uji Duncan, untuk mengetahui beda antar perlakuan berbagai konsentrasi $\mathrm{Cu}$ terhadap jumlah trakea akar eceng gondok. 
Tabel 2. Nilai Rata-rata \pm Standar Deviasi Jumlah Trakea Akar Eceng Gondok akibat Perlakuan Konsentrasi $\mathrm{Cu}$ yang Berbeda

\begin{tabular}{|l|c|}
\hline \multicolumn{1}{|c|}{ Perlakuan } & Rerata \pm Standar Deviasi Jumlah Trakea Akar \\
\hline Konsentrasi Cu 0 ppm & $35,48 \pm 0,97^{\mathrm{d}}$ \\
\hline Konsentrasi Cu 4 ppm & $30,44 \pm 0,76^{\mathrm{c}}$ \\
\hline Konsentrasi Cu 8 ppm & $28,63 \pm 1,34^{\mathrm{b}}$ \\
\hline Konsentrasi Cu $12 \mathrm{ppm}$ & $26,93 \pm 2,38^{\mathrm{a}}$ \\
\hline
\end{tabular}

Keterangan : Nilai rata-rata yang diikuti oleh huruf yang berbeda menunjukkan perbedaan yang nyata berdasarkan Uji Duncan pada taraf 5\%

Dari Tabel 2. dapat dilihat ratarata Jumlah trakea akar eceng gondok semakin tinggi konsetrasi $\mathrm{Cu}$ maka jumlah trakea semakin sedikit. Berdasarkan uji Duncan pada setiap perlakuan berbeda nyata.

\section{Pembahasan}

Dari hasil penelitian diketahui bahwa pada konsentrasi 0 ppm didapatkan jumlah trakea yang lebih banyak karena tumbuhan tidak teracuni oleh logam $\mathrm{Cu}$ sehingga proses metabolismenya berlangsung normal tanpa ada gangguan yang menyebabkan pertumbuhan E. crassipes berjalan optimal, sedangkan pada konsentrasi 4 ppm, 8 ppm dan 12 ppm, diperoleh jumlah trakea lebih sedikit, hal itu disebabkan logam $\mathrm{Cu}$ yang masuk dalam tubuh tumbuhan (Tabel 2).

Akar tanaman E. crassipes dapat menyerap logam berat $\mathrm{Cu}$ dalam bentuk ion-ion yang larut dalam air. Akumulasi logam ke dalam akar melalui bantuan transport ligand dalam membran akar, kemudian akan membentuk transport logam kompleks yang akan menembus xilem dan terus menuju ke sel daun (Borner dan Galstron, 1952 dalam Margiati, 2006).

Masuknya logam berat $\mathrm{Cu}$ pada tubuh tumbuhan akan berpengaruh terhadap proses pembentukan sel-sel trakea. Trakea merupakan bagian dari jaringan xilem yang berfungsi sebagai jaringan pengangkut air dan hara mineral (Suprihatin, 2003).

Sel-sel trakea terbentuk dari proses diferensiasi pada tingkat sel yaitu sel-sel prokambium yang merupakan hasil aktivitas dari meristem apeks (ujung). Dalam proses diferensiasi sel dipengaruhi oleh kerja gen yang akhirnya mengendalikan proses kimia dalam sel sehingga mempengaruhi aktivitas hormon auksin dan sitokinin yang terlibat dalam proses diferensiasi sel-sel trakea. Proses pembentukan trakea diawali dengan terjadinya 
pembelahan sel kemudian terjadi pembesaran sel dilanjutkan dengan diferensiasi sel dengan terbentuknya penebalan dinding ujung sel sekunder dan lignifikasi yang diikuti oleh larutnya dinding ujung sel sehingga terbentuklah struktur yang berbentuk seperti pipa panjang (Hidayat, 1995).

Pembentukan sel trakea membutuhkan peranan enzim dan hormon. Enzim bekerja bila terdapat substrat yang sesuai berikatan dengan sisi aktif dari enzim. Jika substrat berkombinasi dengan enzim, substrat menginduksi perubahan-perubahan dalam struktur sisi aktif enzim sehingga fungsi katalis enzim berlangsung sangat efektif (Sasmitamihardja dan Siregar, 1996), Namun, logam $\mathrm{Cu}$ yang masuk kedalam sel akan berikatan dengan enzim sehingga fungsi enzim sebagai katalisator untuk reaksi-reaksi yang berlangsung didalam sel mengalami gangguan, akibatnya pembentukan sel trakea juga terganggu.

Perubahan pada struktur enzim menyebabkan substrat tidak dapat lagi berikatan dengan enzim sehingga aktivitas katalis enzim akan hilang atau enzim mengalami denaturasi.

Denaturasi enzim bisa disebabkan oleh suhu yang tinggi, zat pengoksidasi dan logam berat seperti $\mathrm{Cu} . \mathrm{Cu}$ yang berikatan pada sisi tidak aktif dari enzim mengganggu kerja enzim dengan mengganti gugus - $\mathrm{SH}$ dengan atom $\mathrm{H}$ menyebabkan perubahan struktur enzim, sehingga substrat tidak dapat berikatan dengan enzim dan akan menghambat kerja enzim. Fungsi enzim yang terganggu menyebabkan kerja hormon juga terganggu (Salisbury dan Ross, 1995).

Hormon juga berperan dalam proses pembentukan sel, seperti hormon sitokinin dan auksin. Hormon sitokinin berperan dalam pembelahan sel (Salisbury dan Ross, 1995). Tetapi peranan hormon sitokinin dipengaruhi oleh kerja enzim. Jika kerja enzim terganggu, kerja hormon sitokinin juga mengalami gangguan dalam memacu pembelahan sel.

Hormon lain yang juga berperan dalam pembentukan sel adalah hormon auksin yang berfungsi memacu pembesaran sel. Auksin dapat menyebabkan $\mathrm{H}^{+}$dari sitosol masuk ke dalam dinding sel. Auksin menstimulasi pemompaan proton $\mathrm{H}^{+}$membran plasma sehingga meningkatkan potensial membran dan menurunkan $\mathrm{pH}$ dalam dinding sel. Pengasaman dinding sel akan mengaktifkan enzim yang 
disebut ekspansin yang bekerja memecah ikatan hidrogen antara mikrofibril selulosa pada dinding sel. Hal ini memungkinkan dinding sel lebih mudah merenggang dan sel akan mengalami pembesaran (Campbell dan Reece, 2002 dalam dewi, 2008), Namun, $\mathrm{Cu}$ yang masuk ke dalam sel akan berikatan dengan enzim ekspansin sehingga menghalangi kerja enzim, mengingat $\mathrm{Cu}$ sebagai inhibitor/ penghambat enzim maka pembesaran sel akan terganggu.

Pertumbuhan yang terganggu dapat diamati secara morfologi daun. Secara morfologi tanaman yang

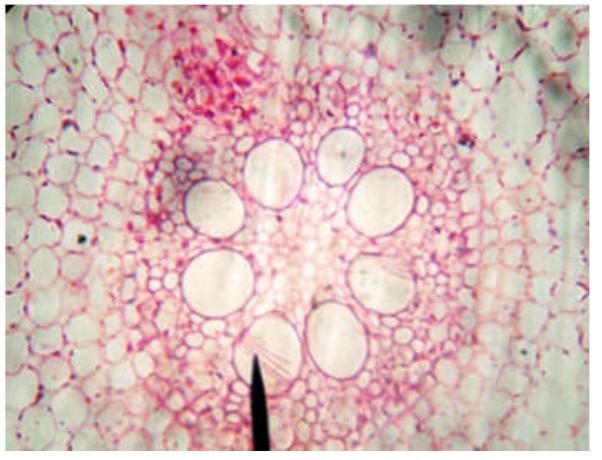

Konsentrasi 0 ppm

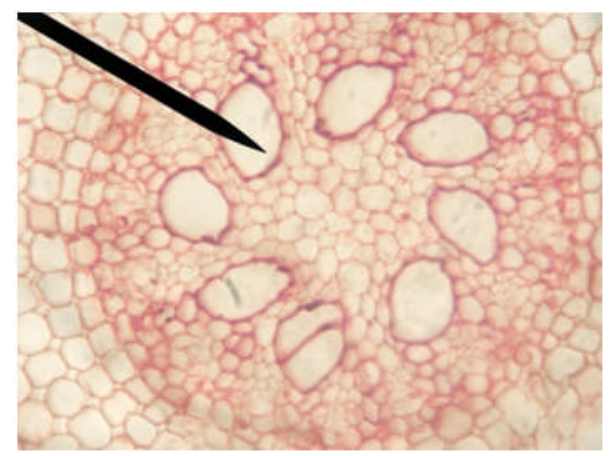

Konsentrasi 8 ppm terpapar logam $\mathrm{Cu}$, daunnya berwarna kekuning-kuningan yang lama kelaman menjadi kecoklatan, dan layu. Secara anatomi terlihat sel-sel trakea terutama pada akar E. crassipes mengalami gangguan dalam pembentukannya sehingga jumlah sel-sel trakea yang terbentuk sedikit dibandingkan dengan sel-sel trakea yang tidak teracuni logam $\mathrm{Cu}$. Secara keseluruhan yang teracuni $\mathrm{Cu}$, struktur sel-sel trakeanya ada yang rusak, kerusakan terjadi pada bagian dinding trakeanya. Struktur dinding trakeanya tidak berbentuk bulat seperti pada trakea yang tidak teracuni logam $\mathrm{Cu}$.

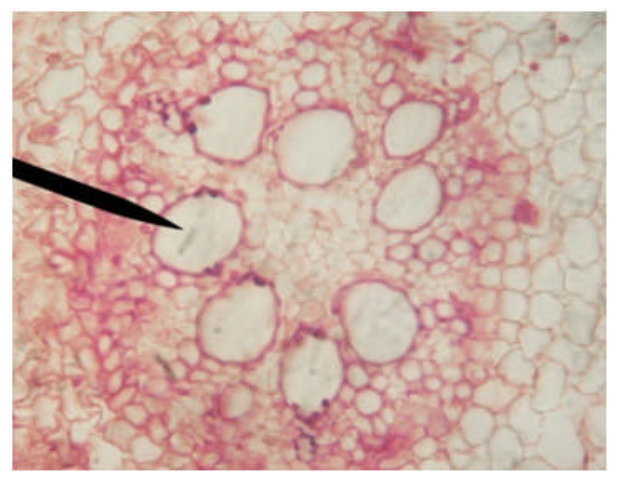

Konsentasi 4 ppm

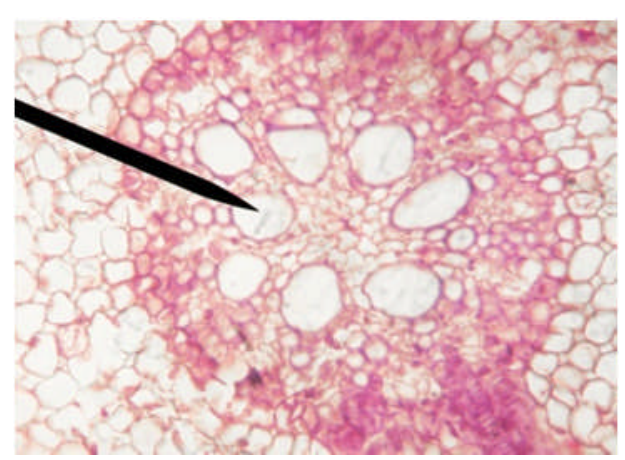

Konsentrasi 12 ppm 


\section{KESIMPULAN}

Kesimpulan yang dapat diambil dari penelitian ini adalah :

Ada perbedaan jumlah trakea akar E. crassipes akibat pemberian $\mathrm{Cu}$ dengan berbagai konsentrasi. Dimana Jumlah trakea akar eceng gondok semakin sedikit dengan perlakuan konsentrasi $\mathrm{Cu}$ yang semakin tinggi.

\section{DAFTAR PUSTAKA}

Amalia, A. 2007. Pengembangan Bioreaktor Untuk

Penyerapan Logam Berat Tembaga $\quad(\mathrm{Cu}) \quad$ Oleh Tanaman Eceng Gondok. Skripsi tidak dipublikasikan. Surabaya: Biologi UNESA.

Budiono, Djoko. 1992. Pembuatan Preparat Mikroskopis: Teori Dan Praktek. Surabaya: Departemen Pendidikan Dan Kebudayaan Institut Keguruan Dan Ilmu Pendidikan Surabaya.

Cahyaningsih, W. D. S. 2004. Pengaruh Pemberian Berbagai

Konsentrasi Timbal (Pb) Terhadap Jumlah Dan Ukuran Diameter Trakea Daun Tapak Dara Air. Skripsi tidak dipublikasikan. Surabaya: Biologi UNESA.

Darmono. 1995. Logam Dalam Sistem Biologi Makhluk Hidup. Jakarta: Universitas Indonesia press.

Dewi, I. R. 2008. Peranan Dan Fungsi

Fitohormon Bagi Pertumbuhan Tanaman. http://pustaka.unpad.ac.id/w pcontent/uploads/2009/ 06/makalah_fitohormo n.pdf
Hardiwibowo, D. 1996. Statistik Praktis Untuk Biologi. Surabaya: UNESA University Press.

Hidayat, E.B. 1995. Anatomi Tumbuhan Berbiji. Bandung: ITB.

Margiati. 2006. Anatomi Akar, Batang, Dan Daun Ipomoea aquatika Forsk Di Kali Surabaya Yang Tercemar Timbal $(\mathrm{Pb})$. Skripsi tidak dipublikasikan. Surabaya: Biologi UNESA.

Palar, H. 2008. Pencemaran Dan Toksikologi Logam Berat. Jakarta: Rineka cipta.

Salibury, F. B dan C. W Ross. 1995. Fisiologi Tumbuhan. Jilid 1, jilid 2 dan jilid 3. (Diah R. L dan Sumaryono). Bandung : ITB.

Sasmitamihardja, D dan A. Siregar. 1996. Fisiologi Tumbuhan. Bandung: ITB.

Suprihatin, Lilik. 2003. Pengaruh Pemberian Berbagai Konsentrasi Kadmium terhadap jumlah trakea daun Jussiaea repens L. Skripsi tidak dipublikasikan. Surabaya: Biologi UNESA.

Suwariyanti, A. 2002. Studi Literatur penurunan Kandungan Logam Berat $(\mathrm{Cu}$ dan $\mathrm{Cd})$ Dalam Limbah Cair Dengan Memanfaatkan Tumbuhan Air. Skripsi tidak dipublikasikan. Surabaya: teknik Lingkungan ITS. 